\title{
Crop establishment systems for winter oilseed rape
}

P D Forristal, K Murphy

Teagasc Crops Centre, Oak Park, Carlow, Ireland

Email: dermot.forristal@teagasc.ie

Introduction Oilseed rape, although a minority crop in Ireland, offers potential benefits as a break crop for cereal growers who find it increasingly difficult to find a market for other break crops. While its use in the production of biodiesel or pure-plant-oil fuel increases the potential market for rapeseed, the crop economics are not favourable, with frequently volatile gross margins achieved. Low-cost production methods must be sought. In Ireland the winter oilseed rape crop is traditionally established with plough-based cultivation and sowing systems. Research from other countries indicates that lower cost minimum tillage (min-till) establishment systems can be successful with oilseed rape (Freer, 2002). The aim of this research was to determine the impact of crop cultivation system, in particular minimum tillage systems, on crop establishment, development and yield.

Materials and methods Eight crop establishment systems were evaluated in each of the years 2007, 2008 and 2009 on different sites. All sites were located close to Oak Park Research centre in the south east of Ireland. The establishment systems were: Plough, press/roll, power harrow/drill, roll (A); Plough, press/roll, cultivator drill, roll (B); Min-till 75100mm 1 run, roll, broadcast sow, roll (C); Min-till 75-100mm 1 run, roll, cultivator drill, roll (D); Min-till 75 - $100 \mathrm{~mm} 2$ runs, roll, cultivator drill, roll (E); Min-till 75-100mm 2 runs, roll, broadcast sow, roll (F); Min-till 150 - $200 \mathrm{~mm} 2$ runs, cultivator drill, roll $(\mathrm{G})$; Broadcast sow $(30 \%$ extra seed), roll $(\mathrm{H})$. The extra seed rate was used in treatment $\mathrm{H}$ as it mimicked commercial practice where poorer establishment rate was expected. The treatments were applied to $30 \mathrm{~m} x 6 \mathrm{~m}$ plots laid out in a randomised block design with 5 replications. A second factor (seed rate) was incorporated by splitting the cultivation plots but these results are not presented. The crops were sown on Aug 29, Sept 7 and Sept 17 in 2007,2008 and 2009 respectively, with a mean seeding rate of $65 \mathrm{seeds} / \mathrm{m}^{2}$ for all treatments except $\mathrm{H}$. The cultivation treatments were applied to the cereal stubble of the previous crop on the day prior to sowing and the day of sowing. Crop agronomy practices such as fertiliser, herbicide and fungicide application were applied uniformly across all cultivation treatment plots following standard production guidelines. Plant establishment was determined approximately five weeks post sowing. Approximately 6 weeks prior to harvest, the oilseed rape canopy structure was assessed by taking 10 full plant samples from each plot and quantifying branching and pod distribution. The plots were harvested following desiccation using a direct-cut plot combine. All data was analysed by ANOVA for split-plot design (Genstat).

Results In each of the trial years, all of the cultivation treatments allowed the crop to be established, grown and harvested successfully. There were considerable year to year differences caused by site differences and particularly weather and its effect on sowing date (Table 1). Late sowing in 2009 resulted in slower establishment, bird damage, and weed control difficulties impacting on yield. There was a significant difference $(\mathrm{P}<0.05)$ in the numbers of plants established each year. Plant structure varied considerably with cultivation system having a significant effect. Generally lower crop establishment resulted in greater levels of stem branching and greater numbers of pods per plant. In 2007 and 2008 this resulted in similar yields being achieved with all crop establishment systems except $\mathrm{H}$ in 2007. In 2009, A, B and H cultivation treatments gave lower yields.

Table 1 Cultivation system effect on plant structure and yields of winter oilseed rape over three seasons.

\begin{tabular}{|c|c|c|c|c|c|c|c|c|c|c|c|c|}
\hline & \multicolumn{4}{|c|}{2007} & \multicolumn{4}{|c|}{2008} & \multicolumn{4}{|c|}{2009} \\
\hline & $\begin{array}{l}\text { Plants } \\
(\mathrm{n} / \mathrm{m} 2)\end{array}$ & $\begin{array}{l}\text { Branches } \\
\text { (n/plant) }\end{array}$ & $\begin{array}{l}\text { Pods } \\
\text { (n/plant) }\end{array}$ & $\begin{array}{l}\text { Yield } \\
\text { (t/ha) }\end{array}$ & $\begin{array}{l}\text { Plants } \\
(\mathrm{n} / \mathrm{m} 2)\end{array}$ & $\begin{array}{l}\text { Branches } \\
\text { (n/plant) }\end{array}$ & $\begin{array}{l}\text { Pods } \\
\text { (n/plant) }\end{array}$ & $\begin{array}{l}\text { Yield } \\
\text { (t/ha) }\end{array}$ & $\begin{array}{l}\text { Plants } \\
(\mathrm{n} / \mathrm{m} 2)\end{array}$ & $\begin{array}{l}\text { Branches } \\
\text { (n/plant) }\end{array}$ & $\begin{array}{l}\text { Pods } \\
\text { (n/plant) }\end{array}$ & $\begin{array}{l}\text { Yield } \\
\text { (t/ha) }\end{array}$ \\
\hline A & 103.6 & 11.1 & 209 & 5.30 & 79.3 & 69.9 & 374 & 4.65 & 70.4 & 12.0 & 210 & 3.54 \\
\hline B & 53.4 & 33.4 & 336 & 5.25 & 56.2 & 69.9 & 355 & 4.56 & 54.2 & 28.4 & 283 & 3.28 \\
\hline $\mathrm{C}$ & 88.8 & 23.4 & 260 & 5.52 & 54.9 & 97.8 & 439 & 4.84 & 60.8 & 39.3 & 314 & 4.46 \\
\hline D & 80.2 & 27.8 & 272 & 5.30 & 55.9 & 69.2 & 344 & 4.65 & 60.3 & 35.5 & 305 & 4.36 \\
\hline $\mathrm{E}$ & 79.0 & 22.0 & 257 & 5.55 & 58.7 & 101.6 & 358 & 4.76 & 61.1 & 39.0 & 351 & 4.23 \\
\hline $\mathrm{F}$ & 75.4 & 43.5 & 304 & 5.42 & 56.3 & 69.4 & 358 & 5.00 & 68.0 & 42.5 & 333 & 4.63 \\
\hline G & 69.3 & 36.0 & 309 & 5.48 & 57.4 & 116.6 & 446 & 4.66 & 65.4 & 33.0 & 273 & 4.17 \\
\hline $\mathrm{H}$ & 76.3 & 40.8 & 313 & 5.05 & 26.1 & 115.8 & 533 & 4.57 & 51.8 & 75.0 & 428 & 2.97 \\
\hline s.e.d & 9.0 & 9.9 & 34 & 0.11 & 4.3 & 23.7 & 76 & 0.15 & 2.8 & 7.6 & 42 & 0.27 \\
\hline $\mathrm{P}$ & $<0.001$ & 0.05 & 0.02 & 0.004 & $<0.001$ & 0.166 & 0.206 & 0.116 & $<0.001$ & $<0.001$ & 0.002 & $<0.001$ \\
\hline
\end{tabular}

Conclusions Minimum tillage crop establishment systems can effectively establish winter oilseed rape, with most of the cultivation systems evaluated producing consistent yields that compare favourably with plough-based establishment systems. While the cultivation system used impacted on plant structure in some seasons, this generally did not impact on seed yield. The simple broadcast sowing method used without cultivation did not perform consistently however.

\section{References}

Freer, B. 2002. HGCA project report no OS55, 27p HGCA Warwickshire, UK. 